Sosyal Bilimler Akademi Dergisi / The Journal of Social Sciences Academy

SOSYAL BILIMLER

-AKADEMIDERGISI-

ISSN: 2636 - 7599
Kitap Kritiği / Book Review

Mayıs / May 2019 Cilt / Volume: 2 Sayı / Issue: 1 Sayfalar: 46-50

\title{
THE ARAB SPRING: THE END OF POSTCOLONIALISM*
}

\section{Mehmet ALKIŞ ${ }^{* *}$}

Marx’ın “İçinde bulunduğumuz zamanın çalışmaları zamanın kendisini ve taleplerini açıklamalıdır” sözü Hamid Dabashi’yi Arap Baharı'nı anlamak için çaba sarfetmesine neden olmuş görünüyor. Dabashi, The Arab Spring: The End of Postcolonialism adlı eseri ile 2011 yılının başında başlayarak Ortadoğu'ya dalga dalga yayılan hareketleri ve bu hareketler içerisinde yer alan insanların taleplerini anlamlandırmaya çalışıyor.

Kitap on bölümden oluşuyor. Mısır'da Tahrir Meydanı'nın en popüler-önemli sloganı olan ve daha sonra Arap Baharı ile özdeşleşen "Al-Sha’b Yurid Isqat al-Nizam” (Halk düzeni devirmek istiyor) sloganından yola çıkarak sağlam teorik bir perspektif ile Ortadoğu'daki değişim dalgasını yorumluyor. Dabashi, düzen ile kastedilenin sadece siyasi sistemin olmadığını aynı zamanda kullanılan bazı terimlerin de çökmekte olduğunu ifade etmektedir. "Ortadoğu", "Kuzey Afrika" ve "Arap-Müslüman Dünya" gibi ifadelerin anlamsızlaştığını ve bölge toplumlarındaki dinamikleri görmeyi salık veriyor. Yaşanan devrim hareketlerinin Avrupa tarihindeki devrimlere benzemeyerek siyasal sistemi değiştirmeden sistemin yeniden yapılandırılmasını talep ettiği belirtiliyor. Kitapta hareketlerin Mihail Bakhtin'in "diyalojik hareketler" kavramından hareketle sonuç odaklı olmadığı ancak amaç ve talepleri olduğunun üstünde sıklıkla duruluyor. Hareketlerin başlangıç noktasını da İran'da 2009 seçimleri sonrasında "Yeşil Hareket"in verdiği ilham olarak belirliyor. Dabashi'nin sıklıkla vurgu yaptı̆̆ diğer bir görüş ise Arap Baharı ile "Doğu-Batı", "seküler-dindar" ayrımlarının ortadan kalktığ1 yönündedir.

Dabashi'nin temel argümanı Arap Baharı'nın gecikmiş bir itiraz olarak sonucu olmayan ve açık uçlu bir süreç olduğudur. Tahrir Meydanı'nın gösterdiği gibi şiddet içermeyen sivil itaatsizlik eylemleri ve şiddetin kategorik reddi bunun en temel göstergesi. Böylece siyasal İslamcılık, milliyetçilik ve Üçüncü Dünya sosyalizmi gibi tepkisel ve postkolonyal hareketlerin sonunun geldiği ileri sürülüyor. Avrupa-merkezci bilgi rejiminin çöpe atılmasının zamanının geldiğini iddia ediyor. Mısır, Tunus, Suriye, Libya ve diğer bölge ülkelerinde görülen hareketlerin Güney Avrupa ve Afrika'yı derinden etkileyerek İslam-Batı ayrımlarını ortadan kaldırdığını belirtmektedir. Dabashi’ye göre “Arap-Müslüman dünyası demokrasiden anlamaz" algısı yıkılarak Arap Baharı bir özgürleşme coğrafyası ortaya çıkarmıştır. National Geographic gibi Batıl1-beyaz-orta/üst sinfflara hitap eden popüler yayınların bu hareketler ile sona yaklaştı̆̆ı tezi oldukça dikkat çekici. Avrupa ve Amerika'nın oluşturduğu Batı dünyası için

\footnotetext{
* Hamid Dabashi, Zed Books, London \& New York, 527 s.

** Arş. Gör. Dicle Üniversitesi, İ̈BF, mmmehmet.alkis@gmail.com, ORCID: 0000-0001-6521-0701
} 
antropoloji bilimi başka toplumları anlamaya yarayan bir araç iken sosyoloji ise kendi toplumları için bir alan olarak ifade ediliyor. $\mathrm{Bu}$ nedenle alternative harita ve anlam dünyalarına ihtiyaç duyuluyor. Doğu-Batı, Güney-Kuzey gibi ayrımların ortadan kalkarak global bir imgeleme gidilmesi gerektiği üzerinde duruyor. Batılıların gözlemci Batıl1-olmayanların ise gözlemlenen olduğu etnografya ve müzelerin işlevsiz kalacağı belirtiliyor. Dünyanın bir gezegen olarak "merkezsiz" olduğu temelinde hareket etmektedir.

Devrimlerin dilinin deşifre edilmesi Dabashi'ye göre büyük bir ihtiyaç olarak ortaya çıkmaktadır. Hareketlere katılanların sosyal medya yoluyla mobilize olduğu, şiddet içermeyen eylemlerde bulunduğu ve orta-sınıflardan geldiği tespitinde bulunuluyor. Sosyal medyanın küresel hale gelmesi Oryantalizmin yeniden yorumlama yeteneğini imkansız k1lıyor. Al Jazeera ve Jadaliyya gibi Batı-dışı yayınların etkisinin önemine dikkat çekiliyor. Özgürlük, sosyal adalet ve onur gibi kavramlar hareketin dilinin ana repertuvarını oluşturuyor. Ortaya çıkan dil ne İslamcı, ne anti-İslamcı, ne seküler, ne dindar, ne Batılı ne de Doğulu. Derridacı "bağlam"da difference (fark) söz konusudur. Yani herkes kendi kimliğiyle ve talepleriyle meydandadır. Böylece bu dil ile yeni muhataplar ortaya çıkmaktadır. Dabashi'nin en vurucu ifadesi ise şu oluyor:

"Bu gelişmelerin en önemli küresel sonucu şimdiye kadar görmezden gelinmiş ve önemsenmemiş olanın alternatif siyasi ve duygusal bir coğrafya olarak ortaya çıkmasıdır",

Dabashi'ye göre isyan hareketlerinin en önemli özelliklerinden biri Amerika Birleşik Devletleri ve İsrail'e düşman olan yönetimlere karşı olduğu kadar dost olan yönetimlere de karşı geliştiğidir. Bu açıdan İran ve yanlısı olan aktörlerin bu hareketleri İsrail ve Amerikan kurgusu olduğu iddiası boşa çıkmaktadır.

Arap Baharı'nın bilgi rejiminde yaptığı değişim Ortadoğu Çalışmaları alanının hazırlıksız yakalanmasına neden olmuştur. İran'daki Yeşil Hareket Dabashi için İslam Cumhuriyeti ve bölgedeki jeopolitikte değişikliğe neden olmuştur. Ortadoğu'da düşman kaybetmek dost kaybetmekten daha kötüdür. Kolonyalizmin temsilcisi olarak gördüğü hem Amerika ve İsrail, hem de postkolonyalizmin temsilcisi İran kaybetmiştir. İran'da rejim Mısır'da devrimi "İslami uyanış" olarak nitelerken Amerika'da neo-con'lar "İslam Devrimi” ifadesini kullanmıştır. Dabashi her iki zıt aktörün aslında aynı dili kullandığına dikkat çekmek istiyor.

Kitabın temel iddialarından biri Arap Baharı'nın postkolonyal ideolojik oluşumların sonunu getirdiği yönünde. Postkolonyalizmin sonu aslında kolonyal bağlam ve terimlerin de üretilmesinin sonunu getiriyor. Avrupa'nın kolonyal etkisi bölgede diktatör postkolonyal yönetimleri (sömürge karşıtı, milliyetçi, sosyalist ve İslamcı) iktidara getirmişti. Dabashi’ye göre Ortadoğu'da İsrail ve Amerika'nın devri sona erdi ve sıra artık Araplarda. Bölgede Batı-Doğu

\footnotetext{
${ }^{1}$ s. 187.
} 
ayrımını yapmak artık mümkün değil. Atina ve Kahire demokrasi talebi ekseninde buluşabiliyor.

Devrim hareketlerinin başlangıcı olarak gördüğü Yeşil Hareket gerçek başarısına Tunus ve Mısır'da ulaşmıştır. 2009 yılındaki hareket tüm bölge için bir ilham kaynağı olarak gösteriliyor. Yeşil Hareketi post-ideolojik ve sivil haklar temelinde ele alıyor. İslam'1 ideoloji olarak ele alan hareketlerin yolun sonuna geldiğini belirtiyor. Dabashi'nin burada temel aldığ 1 şey İslam'ın tarih içinde Yunan felsefesi, Yahudi teolojisi, Hristiyan çileciliği ve son iki yüzyılda da Avrupa kolonyalizmi ile muhatap olduğu tespitini yapıyor. Bundan böyle monolog bir teoloji olarak devam edemeyeceğini ve İslam için yapılması gereken bir özgürleşim teolojisi halini almasının sağlanması gerektiğidir. Post-ideolojik ifadesi ile postkolonyal şartlar altında üretilen ideolojilerin sonunu kastetmektedir. Karl Mannheim'dan ilham alarak siyasal İslamcılığı tepkisel bir ideoloji olarak görür ve diğer postkolonyal ideolojilerin de kolonyalizm ile olan diyalojik ilişkilerinin açığa düştüğünü ifade eder. Küreselleşme süreçleri ile postmodern dünyada artık bir merkezin olmadığını ileri sürer. Post-ideolojik çağın iki sonucu bulunmaktadır: Birincisi; devlet ve iktidar merkezli siyasal modernleşme yerini toplumun kendi dinamikleriyle değişip dönüştüğü toplumsal modernleşmeye bırakmıştır. İkncisi; herkes için evrensel ve genel önermelerde bulunan kamusal akıl, ideolojik düşünmenin ötesine geçen ve açık uçlu devrim düşüncesini benimseyen estetik akıl karşısında yenilmiştir.

Dabashi kitabın ilerleyen bölümlerinde devrimlerde etkili olan grupları ele almaktadır. Farklı 1rk, etnik grup ve cinsiyetlerden insanlar bir araya gelerek sistemi değiştirme arayışında olmuştur. Özellikle kadınların rolüne dikkat çekmektedir. Batılı-oryantalist klişelerde Müslüman kadın; bastırılmış, kıstırılmış ve önemsiz olarak betimlenmiştir. Ancak Arap Baharı'nın önemli aktörlerinden kadınlar Mısır ve Tunus'ta durumun böyle olmadığını göstermiştir. Kadın hareketi böylece kolonyalizmi, Judith Butler'ın toplumsal cinsiyetin sosyal ve psikolojik olarak inşa edildiği görüşü bağlamında yapısöküme uğratmıştır.

Kolonyalizm hakkında böyle bir düşünceye sahipken Libya'ya yapılan NATO ve Avrupa müdahalesi Dabashi'yi zor durumda bırakmıştır. Kendisine göre yapılan bu müdahale Arap Baharı'nın ruhunu olumsuz etkilemiştir. Savaşçıl olmayan ve şiddet içermeyen olaylara Libya hükümetinin sert müdahalesi böyle bir sonuç doğurdu. Demokratik kazanımlar açısından Arap Baharı kolonyal güçleri gereksiz bırakmıştı.

Arap Baharı olayları sırasında ana-akım küresel medyada yapılan yorum orta sınıfların Amerika-Avrupa tarzı demokrasiyi talep ettiği ve küresel kapitalizme entegre olmayı istedikleri yönünde olmuştur. Dabashi bu görüşe kesinlikle karşı çıkarak verili çerçevelerden kurtulmak gerektiğini söyler. Arap Baharı'nı anlamak için bakılması gereken yer New York Times ve The Economist değil isyanları anlatan filmler, şiirler ve şarkılardır. $\mathrm{Bu}$ toplumların demokrasiye yatkın olmadıklarını ileri sürmek patolojiden başka bir şey değildir. Umberto Eco'nun 
hermenötiğinden hareketle halkın sesine kulak vermeyi, devrimlerdeki aşkınsallığı, onurlu yaşam talebini ve görülmeyenin sesini duymak gerektiğini belirtir.

Sonuç olarak Dabashi kitabı şöyle bitirmektedir. Yeşil Hareket ve Arap Baharı'nı birbirinden bağımsız düşünmek çok zor. Devrimleri insanlar yapar, insanları da devrimler yapar. Karşılıklı bir etkileşim söz konusudur. Bu devrim hareketlerinin en önemli özelliği açık uçlu olması, postkolonyalizmin sonunu getirmesi, post-ideolojik bir durum ile hiçbir liderinin olmaması ve mücadelenin kamusal alanda olmasıdır. Bilgi rejiminde neden olduğu değişklik ile anti-kolonyal hareket ve düşüncelerin sonunu getirmiştir. Şu alıntı Dabashi'nin görüşlerini özetler niteliktedir:

"Arap Baharı bir sonuca ulaşmak değil, bir doğumdur. Postkolonyalizmin sonu ile şunu anlatıyorum: Arap Baharı ideolojilerin ulaşmak istediği bir sonuç değildir aksine tüm ideolojilerin tükendiği doğum anıdır. Bundan dolayı miras aldı̆̆ımı régime du savoir (bilgi sistemi) yararsızdır ve karşıtını üretmekten başka bir işe yaramamaktadır."’2

Dabashi genel olarak yukarıda ifade edilen çerçeve etrafında Arap Baharı'nı yorumlamaktadır. Kitabın en güçlü olduğu yönü sağlam teorik bir zeminde görüşleri temellendirmesidir. Sosyoloji, antropoloji, siyaset bilimi ve uluslararası ilişkiler alanlarından yararlanarak geniş bir çerçeve sunmaya çalışıyor. Özellikle Mihail Bakhtin, Karl Mannheim ve Jacques Derrida gibi isimlere referans yaparak kolonyalizm-postkolonyalizm çelişkisini aşmaya çalışması dikkate değer. Bu bağlamda Üçüncü Dünya sosyalizmi, anti-kolonyal milliyetçilik ve siyasal İslamcılık gibi ideolojilerin sonunu ilan etmesi ile birlikte Ortadoğu'ya ilişkin klişe ve bilgi sisteminin çöktüğü argümanı dikkat çekmektedir. Diğer katkılarından biri de İslam ve geleceği ile ilgili tartışmalar için bir vizyon sunmasıdır. İslam'ın monolog bir teoloji ve her şeyi kuşatan ideoloji olmaktan çıkarılarak "kurtuluş teolojisi" olması gerektiği yerinde bir tespit. Yine buradan hareketle kamusal alan tartışmalarında dinin yerine ilişkin görüşleri ikna edicidir. Benzer bir biçimde Arap Baharı protestolarına katılan insanların profilini sunması önemlidir.

Kitapta Dabashi'nin eleştirileceği noktaların başında İran'daki Yeşil Hareketi Arap Baharı'nın başlangıcı olarak görmesi gelmektedir. Buraya yaptı̆̆ı vurgunun kitabın birçok bölümünde görülmesi eleştiri yapmayı gerekli kılmaktadır. Arap Baharı gibi dünya siyasetinde çok etkili olan bir olayı ele alırken uluslararası ilişkiler disiplininden yeterince yararlanmaması da eksik olarak görülebilir. Bu açıdan Libya'ya yapılan müdahale Dabashi’nin görüşlerinin kendisinin belirttiği üzere- en azından bir kısmının temellendirilmesi sorununa neden olabilmektedir. Yazıldığı dönemde Arap Baharı'nın iyimserliğini taşımakla birlikte Ortadoğu'da yaşanan gelişmeler ilk döenmlerdeki iyimserliği ortadan kaldırmış ve çalışmanın öngörüsünü de kısıtlamış görünmektedir.

\footnotetext{
2 s. 433.
} 
Dabashi bu eseri ile Arap Baharı'nı güçlü bir zeminden hareketle yorumlamaya çalışmaktadır. Yazıldığı dönemin iyimserliğini birleştirdiği sürekleyici ve etkili diliyle yaşanan olayların anlaşılmasını kolaylaştırmaktadır. Arap Baharı'nın sonraki dönemlerde geldiği nokta, bu iyimserliğin ortadan kalkmasına ihtimalini doğurmakla beraber "zamanı ve taleplerini anlamak" için oldukça ufuk açıcı bir eser olarak dikkat çekmektedir. 